\title{
KEARIFAN EKOLOGIS BUDAYA LOKAL MASYARAKAT ADAT CIGUGUR SEBAGAI SUMBER BELAJAR IPS
}

\author{
Mina Holilah, Prodi Pendidikan IPS, SPs, UPI.
}

\begin{abstract}
ABSTRAK
Cara pandang antroposentris menempatkan manusia untuk mengeksploitasi alam dengan mengabaikan keberlangsungan sistem ekologi. Penanaman nilai-nilai kearifan ekologis melalui budaya lokal masyarakat Cigugur merupakan salah satu upaya pewarisan nilai luhur untuk menjaga keseimbangan sistem ekologi khususnya bagi masyarakat Kabupaten Kuningan. Kajian utama penelitian ini adalah identifikasi nilai-nilai kearifan ekologis budaya lokal masyarakat Cigugur Kuningan dan bagaimana mengimplementasikan nilai-nilai tersebut dalam pembelajaran IPS di SMP N 2 Garawangi Kelas VII A. Hasil penelitian menunjukkan bahwa masyarakat adat Cigugur memiliki nilai-nilai kearifan ekologis yang dapat digunakan sebagai sumber belajar IPS meliputi nilai pelestarian lingkungan, mitigasi bencana, dan pola konsumsi ramah lingkungan. Nilai pelestarian lingkungan terdiri dari pola pertanian, penjagaan leuweung larangan, pelestarian mata air / cainyusu, serta nilai filosofis upacara Seren Taun. Nilai mitigasi bencana dan pola konsumsi ramah lingkungan terdapat dalam petuah/larangan yang masih digunakan sebagai pedoman kehidupan sehari-hari. Implementasi nilai kearifan ekologis budaya lokal masyarakat adat Cigugur dalam pembelajaran IPS di SMP N 2 Garawangi kelas VII A menunjukkan hasil yang baik. Peserta didik memiliki antusiasme dan rasa ingin tahu mendalam terhadap budaya lokal masyarakat adat Cigugur untuk menanamkan nilai-nilai kearifan ekologis dalam kehidupan sehari-hari mereka. Penelitian ini merekomendasikan supaya dijadikan rujukan bagi pengembangan pembelajaran IPS berbasis budaya lokal di berbagai sekolah khususnya Jawa Barat.
\end{abstract}

Kata kunci : Kearifan Ekologis, Budaya Lokal, Cigugur Kuningan, Pembelajaran IPS.

\section{PENDAHULUAN}

Dinamika kehidupan manusia mengharuskan terjadinya pola interaksi dan adaptasi dengan lingkungan alam sekitar. Mereka hidup di bumi bersama makhluk hidup lain terkait erat dalam hubungan yang berlangsung harmonis. Manusia berupaya memenuhi kebutuhan hidupnya dengan memanfaatkan alam sekitarnya, namun pada level tertentu mereka melakukan eksploitasi berlebihan terhadap alam yang menyebabkan kerusakan alam. Hubungan harmonis tersebut pada akhirnya terganggu dengan adanya tindakantindakan manusia merusak lingkungan demi kepentingannya sendiri. Terjadi kerusakan alam berupa pencemaran unsur-unsur biotik dan abiotik sehingga keseimbangan mulai terganggu. Kondisi ini sangat mengkhawatirkan bagi kelangsungan hidup manusia di masa mendatang karena harus diakui kehidupan manusia sangat bergantung pada lingkungan sekitarnya. Chew (2001, hlm. 11) bahwa cara pandang antroposentis yang menempatkan manusia sebagai pusat di muka bumi ini menyebabkan terjadinya degradasi lingkungan berbagai kawasan dunia. Akibatnya alam menunjukkan kemurkaan berupa bencana yang mengancam kehidupan manusia di bumi. Tindakan manusia mengeksploitasi alam membawa konsekuensi terganggunya keseim-bangan ekosistem, seperti diungkapkan oleh Kahn (2010, hlm. 3) sebagai berikut : 
Over the last fifty to sixty years, then, a particularly noxious economic paradigm has unfolded like a shock wave across the face of the earth, one that has led to an exponential increase of global capital and startling achievements in science and technology, but which has also devastating effects upon ecosystems both individually and taken as a whole.... environmental degradation results from fundamental sociocultural, political, and economic inequalities.

Kerusakan lingkungan seharusnya dapat diminimalisir dengan cara mengendalikan keserakahan manusia dalam mengeksploitasi alam. Manusia harus ditempatkan sebagai bagian dari alam ini dan bukan sebaliknya terpisah dari alam seperti menurut Costanza (2007, hlm. 522)“'humans are part of nature not separated from it".

Eksplorasi nilai-nilai kearifan ekologis dilatarbelakangi oleh semakin meningkatnya kerusakan lingkungan seperti polusi udara, air, dan tanah yang disebabkan oleh tindakan manusia. Perusakan alam yang berdampak buruk bagi keseimbangan ekosistem harus segera diatasi melalui pengembangan pendidikan berbasis lingkungan. Kesadaran lingkungan diperlukan agar masyarakat memiliki pengetahuan, sikap, dan keterampilan hidup yang ramah dengan lingkungan. Kesadaran akan hidup selaras dengan alam tidak hanya termanifestasikan dalam slogan semata melainkan harus diimplementasikan dalam kehidupan sehari-hari masyarakat.

Kearifan ekologis dapat dikembangkan melalui proses pembelajaran dengan menggunakan sumber belajar yang digali dari budaya lokal masyarakat tradisi. Berbagai suku di Indonesia memiliki tradisi yang di dalamnya mengandung unsur budaya lokal. Budaya lokal seperti itu memiliki nilai yang sangat tinggi untuk diangkat oleh masyarakat modern pada masa kini yang dihadapkan pada ancaman kerusakan lingkungan. Budaya lokal dalam masyarakat tradisi di berbagai daerah dapat digali sebagai sumber belajar, dikaji, dan dikembangkan untuk mengembangkan kearifan ekologis. Adimihardja (2008:72), "Budaya lokal secara dominan diwarnai nilainilai adat, seperti bagaimana suatu kelompok sosial melakukan prinsip-prinsip konservasi, manajemen dan eksploitasi sumber daya alam. Hal ini tampak pada perilaku mereka yang memiliki rasa hormat begitu tinggi terhadap lingkungan alam yang menjadi bagian tidak terpisahkan dari kehidupannya.

Cigugur merupakan salah satu kecamatan di Kabupaten Kuningan dimana masyarakatnya masih mempertahankan nilai-nilai budaya lokal dalam menjaga keselarasan hidup dengan lingkungan. Diantaranya terdapat ritual Adat Seren Taun yang sudah berlangsung sejak 1937, bermakna syukuran atas karunia panen padi yang melimpah. Selain itu, terdapat nilai dan norma dalam menjaga lingkungan seperti konsep pamali, papatah karuhun, dan lainnya yang dijadikan pedoman dalam kehidupan sehari-hari masyarakat.

Masyarakat Cigugur memiliki akar budaya lokal yang erat kaitannya dengan pola hidup selaras paradigma ecosentrisme. Budaya lokal tersebut berupa kearifan dalam pemilihan bentuk arsitektur rumah, konsep leuweung larangan, cara menjaga air hulu dan hilir, keyakinan pada tanda-tanda alam, konsep " $c i$ " atau "lemah cai", pola tanam, pola konsumsi, pola kehidupan ekonomi, dan hubungan interaksi sosial. Nilai-nilai luhur yang dipegang teguh menjadi pedoman pelaksanaan kehidupan sehari-hari. Lingkungan sekitar berupa pesawahan, hutan, dan gunung menjadikan mereka bertindak secara arif dalam berinteraksi dan beradaptasi dengan alam. Budaya lokal menjadi manifestasi ide dan perilaku masyarakat adat Cigugur yang 
sarat nilai-nilai kearifan ekologis. Local genius masyarakat Cigugur memiliki kelebihan untuk beradaptasi dengan lingkungan, sehingga alam tidak lagi menjadi musuh mereka melainkan dijadikan sebagai sahabat untuk hidup selaras.

Kemampuan masyarakat Cigugur dalam membaca tanda-tanda alam menjadi sebuah kekuatan masyarakat lokal sebagai implikasi seperti diungkapkan Goleman (2012:13) sebagai community practice.

Implementasi nilai-nilai budaya lokal berkaitan dengan kearifan ekologis sebagai sumber belajar IPS diharapkan dapat memberikan pengalaman belajar lebih bermakna bagi peserta didik. Mereka akan lebih dekat dengan lingkungan sekitar dalam kehidupan sehari-hari yang lebih nyata. Implementasi nilai budaya lokal masyarakat dalam pembelajaran IPS dikembangkan di SMP sebagai upaya mentransformasikan nilai-nilai budaya yang mengakomodir segala kebutuhan peserta didik baik pewarisan nilai budaya, pengembangan intelektual, serta mempersiapkannya menjadi warga masyarakat mampu berpartisipasi positif di lingkungannya.

Implementasi tersebut sifatnya sangat penting karena masih terdapat permasalahan yang berkaitan dengan pengembangan pembelajaran IPS di sekolah, seperti masih terbatasnya sumber belajar IPS yang masih terpaku pada buku teks dan LKS. Pembelajaran yang terpaku pada buku teks menjadikan pembelajaran IPS hanya berorientasi pada materi, sementara peserta didik dijauhkan dari fenomena di lingkungan sekitar tempat tinggalnya.

Inovasi pembelajaran IPS sangat diperlukan untuk mengembangkan pembelajaran bermakna. Guru perlu mengembangkan kreativitas dalam mengelola pembelajaran IPS dengan kemasan menarik seperti mengimple- mentasikan metode pembelajaran berbasis lingkungan.

Nilai-nilai kearifan ekologis dalam budaya lokal masyarakat Cigugur Kuningan menjadi salah satu alternatif sumber belajar IPS yang mumpuni untuk menciptakan pembelajaran IPS bermakna. Penggunaan budaya lokal sebagai sumber belajar IPS memfasilitasi peserta didik memahami secara langsung konten materi yang dikorelasikan dengan kondisi kehidupan sehari-hari di sekitar tempat tinggal peserta didik. Dengan demikian nilainilai kearifan ekologis menjadi salah satu sumber nilai dalam mengembangkan pembelajaran IPS yang bertujuan untuk meningkatkan kepedulian peserta didik dalam pelestarian lingkungan.

\section{HASIL DAN PEMBAHASAN \\ Deskripsi Masyarakat Adat Cigugur}

Masyarakat Adat Cigugur ditujukan pada kelompok masyarakat adat yang tinggal di lingkungan Paseban Tri Panca Tunggal Kecamatan Cigugur. Keberadaan masyarakat Adat Cigugur tidak terlepas dari rangkaian historis perlawanan terhadap penjajahan Belanda di Kabupaten Kuningan. Secara historis masyarakat adat Cigugur diprakarsai oleh Pangeran Sadewa Alibasa atau lebih dikenal sebagai Madrais. Madrais merupakan keturunan Pangeran Gebang, yaitu wilayah pecahan dari Kesultanan Cirebon yang kini menjadi wilayah Kabupaten Kuningan. Pemaparan mengenai asal usul madrais ini diuraikan dalam dokumen masyarakat adat Cigugur yang disusun kembali oleh Yayasan Trimulya Cigugur (1998, hlm. 3). Dokumen tersebut menguraikan sebagai berikut :

Madrais bernama Sadewa Alibassa Wijayakusuma Ningrat atau dikenal dengan nama Pangeran Surya Nata. Saat berusia 10 
tahun, Madrais bekerja pada Kuwu Sagarahiang sebagai penggembala kerbau. Baru sekitar 1840 nama Kiai Madrais mulai dikenal di Cigugur. Pada masa itu, Ki Madrais sering berkelana keluar masuk Cigugur hingga akhirnya menetap di desa itu. Di desa inilah Kiai Madrais mendirikan pesantren dengan mengajarkan agama Islam. Kepada santri-santrinya, dia selalu mengingatkan untuk dapat lebih menghargai cara dan ciri kebangsaan sendiri Jati Sunda.

Peranan Madrais sebagai pemrakarsa pertama Tri Panca Tunggal, pengaruhnya cukup luas di masyarakat bukan hanya dalam sistem kepercayaan, melainkan juga dalam berbagai aspek kehidupan kemasyarakatan. Madrais mampu merangkul masyarakat pribumi dari berbagai agama dan juga aliran kepercayaan. Dalam sejarahnya ajaran Madrais ini sempat dinyatakan sesat karena selain mengajarkan agama Islam, diuraikan pula ajaran dari agama lain dan mencapai titik temu pada Ketuhanan yang Maha Esa. Selain itu, ajarannya juga senantiasa dikaitkan dengan jati diri kebanggaan masyarakat Sunda yang memiliki budaya dan karakter yang khas. Karena banyaknya masyarakat yang berminat untuk belajar pada Madrais, lama kelamaan terbentuklah kelompok masyarakat adat Cigugur.

Kepemimpinan masyarakat adat kemudian dilanjutkan oleh anak Pangeran Tedjabuana yaitu Pangeran Djatikusuma yang pada tanggal 11 Juli 1981 mendirikan Paguyuban Adat Cara Karuhun Urang (PACKU). Saat ini Pangeran Djatikusuma telah mempersiapkan anak laki-laki satu-satunya, yaitu Pangeran Gumirat Barna Alam untuk meneruskan ajaran ini. Menurut ajaran Kiai Madrais anak lelaki harus bersikap netral, dan dapat mengerti semua agama. Sementara anak-anak Djatikusuma lainnya bebas memilih agama ataupun kepercayaan lain. Perkembangan berikutnya setelah wafatnya Madrais, para keturunannya meneruskan apa yang telah diwariskan kepada mereka. Anak cucu Madrais semakin terbuka dalam masyarakat adat tidak lagi terfokus pada ajaran-ajaran berkaitan religi, melainkan juga terlibat aktif dalam kehidupan kemasyarakatan lainnya yang lebih luas.

Melalui surat keputusan Direktur Direktorat Sejarah dan Purbakala RI tanggal 14 Desember 1976, No. 3632/C.1/DSP/1976 yang menetapkan Gedung Paseban Tri Panca Tunggal sebagai Cagar Budaya dilindungi, maka masyarakat adat Cigugur turut pula dijadikan sebagai masyarakat adat yang memiliki karakteristik budaya lokal yang khas. Keberadaannya hingga kini menjadi masyarakat adat yang memiliki sistem budaya dan perilaku hidup berkarakter lokalitas masyarakat sunda yang dipertahankan. Karakter budaya sunda tersebut berimplikasi pada karakter lain yang mengiringinya berupa tata aturan dan perilaku kehidupan sehari-hari yang disepakati bersama oleh masyarakat adat Cigugur termasuk nilai-nilai kearifan ekologis untuk menunjang keberlangsungan alam sekitarnya yang dipertahankan hingga saat ini.

Keberadaan masyarakat adat Cigugur memiliki peranan penting (power of society) bagi masyarakat sekitar khususnya bagi masyarakat Kecamatan Cigugur, umumnya masyarakat Kabupaten Kuningan Jawa Barat. Saat ini keberadaan masyarakatnya menjadi sentral pengembangan kebudayaan di Kabupaten Kuningan dengan berbagai ritual budaya diantaranya Upacara Seren Taun yang rutin dilaksanakan tiap tahun pada tanggal 18-22 Rayagung sebagai wujud syukuran atas nikmat panen yang melimpah. Selain ritual budaya yang rutin dilaksanakan, masyarakat adat Cigugur juga memiliki nilai kearifan ekologis dalam praktik kehidupan sehari-hari dan nilainilai makna filosofis yang diyakini oleh masyarakat. 
Gambar 1. Peta Wilayah Kecamatan Cigugur

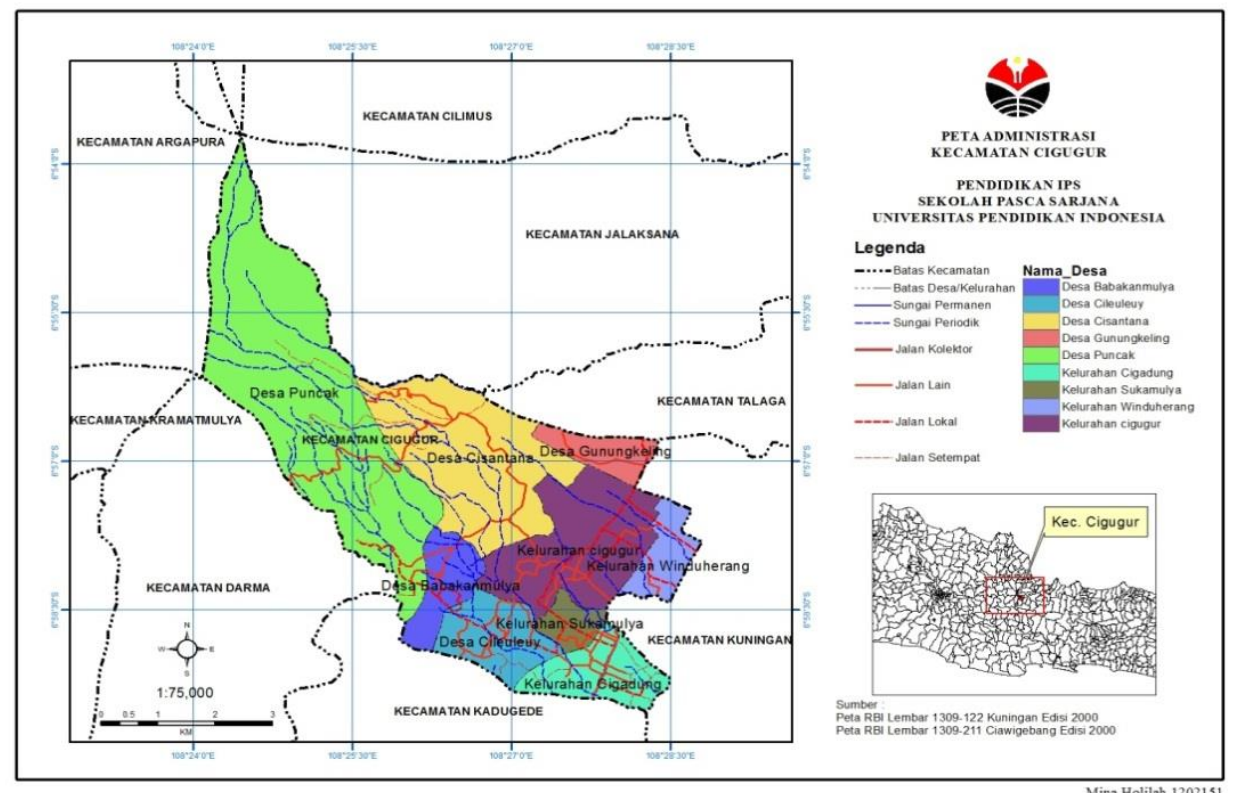

\section{Kondisi Geografis}

Kecamatan Cigugur terletak di sebelah barat Kabupaten Kuningan. Wilayahnya terdiri dari lima desa dan lima kelurahan yaitu Desa Puncak, Cileuleuy, Babakan Mulya, Cisantana, dan Gunung Keling serta Kelurahan Cigugur, Cigadung, Sukamulya, Winduherang, dan Cipari. Ketinggian \pm 700 meter dari permukaan laut di kaki Gunung Ciremai, berjarak 3,5 KM dari pusat Kota Kuningan. Sebelah utara berbatasan dengan Kecamatan Karamatmulya, sebelah selatan berbatasan dengan Kecamatan Kadugede, sebelah barat berbatasan dengan Kabupaten Majalengka, dan sebelah timur berbatasan dengan Kecamatan Kuningan.

Kecamatan Cigugur memiliki iklim tropis dengan curah hujan mencapai 2000-4000 $\mathrm{mm} /$ tahun. Letaknya berada di perbukitan sebagai daerah resapan air hujan sehingga terdapat banyak mata air atau disebut masyarakat sekitar sebagai cainyusu. Cainyusu tersebar di beberapa daerah seperti di Cigugur, Citiis (Kelurahan Cileuleuy), Palutungan, Ciputri (Desa Cisantana), dan Cipari. Mata air tersebut digunakan untuk memenuhi kebutuhan hidup masyarakat seperti minum, irigasi, dan perikanan. Menurut data BPS Kabupaten Kuningan (2013:21) wilayah Kecamatan Cigugur memiliki luas 3.357.556 Ha dengan rincian pemanfaatan lahan $692.843 \mathrm{Ha}$ sebagai area pertanian produktif, area tanah kering/ tegalan seluas 1.555.935 $\mathrm{Ha}$, dan wilayah hutan $950.685 \mathrm{Ha}$. Pemanfaatan lahan tersebut menjadikan wilayah Kecamatan Cigugur menjadi wilayah hijau yang diperuntukkan untuk lahan pertanian dan ladang.

Melalui visi "terwujudnya Cigugur sebagai daerah wisata dan budaya berbasiskan pertanian yang tangguh dengan berlandaskan kerukunan umat beragama yang berorientasi kepada agribisnis dan agrowisata", Cigugur menekankan konsentrasi kehidupan masyarakat pada lingkungan alam sekitarnya. Menurut Camat Cigugur, Beni Prihayatno (wawancara 28 Maret 2014) menyatakan bahwa kondisi geografis Cigugur memungkinkan sebagian besar masyarakat bergantung kehidupannya pada sektor pertanian. Selain itu kawasan hutan yang luas memberikan dampak positif ketersediaan sumber daya alam yang melimpah bagi kebutuhan hidup masyarakat. Alam memiliki fungsi yang sangat penting 
bagi kehidupan sehari-hari masyarakat, meskipun sebagian masyarakat sudah bekerja di sektor publik non-agraris akan tetapi alam masih menjadi faktor dominan penunjang keberlangsungan hidup masyarakat.

Data BPS Kabupaten Kuningan (2013:96) jumlah penduduk Kecamatan Cigugur tahun 2012 adalah 44.573 jiwa dengan usia produktif antara 15-49 tahun sebanyak 26.064 jiwa. Dengan demikian, $50 \%$ penduduk memiliki potensi produktif untuk mengelola sumber daya alam yang ada di wilayah ini. Penduduk yang produktif menjadi modal dasar dalam pembangunan dan kemajuan suatu daerah. Diharapkan Kecamatan Cigugur menjadi salah satu kecarnatan yang berkembang dan maju namun tetap memperhatikan keselarasan hidup dengan sesama dan lingkungan. Berikut data BPS Kabupaten Kuningan mengenai jumlah penduduk di Kecamatan Cigugur pada tahun 2012 berdasarkan jenis kelamin dari tiap desa dan kelurahan.

Tabel 1. Penduduk Kecamatan Cigugur Berdasarkan Jenis Kelamin
\begin{tabular}{cllccc} 
No & \multirow{2}{*}{$\begin{array}{c}\text { Nama } \\
\text { Desa/Kelurahan }\end{array}$} & \multicolumn{3}{c}{ Jumlah } & Total \\
\cline { 2 - 4 } & Laki-laki & Perempuan & \\
\hline 1. & Puncak & 2.077 & 1.955 & 4.032 \\
\hline 2. & Cileuleuy & 1.927 & 1.848 & 3.775 \\
\hline 3. & Babakan Mulya & 1.986 & 1.338 & 3.324 \\
\hline 4. & Cisantana & 3.199 & 2.985 & 6.184 \\
\hline 5. & Gunungkeling & 1.284 & 974 & 2.258 \\
\hline 6. & Cigugur & 3.403 & 3.091 & 6.494 \\
\hline 7. & Cigadung & 2.970 & 2.604 & 5.574 \\
\hline 8. & Sukamulya & 2.785 & 2.841 & 5.626 \\
\hline 9. & Winduherang & 2.103 & 1.956 & 4.059 \\
\hline 10. & Cipari & 1.815 & 1.432 & 3.247 \\
\hline & Jumlah & 23.549 & 21.024 & 44.573 \\
\hline
\end{tabular}

Sumber : BPS Kabupaten Kuningan (2013, hlm. 96)

Tabel 1 menunjukkan proporsi jumlah penduduk berdasarkan jenis kelamin berada pada posisi setara antara laki-laki dan perempuan. Hal ini memberikan gambaran bahwa masyarakat Cigugur memiliki sumber daya manusia cukup mumpuni dan merata dalam mengelola potensi alam yang tersedia. Jumlah penduduk Kelurahan Cigugur sebagai lokasi keberadaan masyarakat adat Cigugur, memiliki jumlah penduduk yang sedikit lebih dominan dibandingkan desa dan kelurahan lainnya di Kecamatan Cigugur yaitu sebanyak 6.494 jiwa. Jumlah tersebut menjadi salah satu indikator tingginya kebutuhan masyarakat dalam memenuhi kebutuhan hidup sehari-hari. Dengan demikian, potensi alam yang dimiliki akan dimanfaatkan seoptimal mungkin oleh masyarakat sekitar. Pemanfaatan alam tersebut memberikan dampak secara bersamaan baik dampak positif maupun dampak negatif. Dampak positif yang ditimbulkan adalah pengelolaan alam dapat dilakukan secara optimal oleh masyarakat, namun di sisi lain terdapat kekhawatiran di masa yang akan datang kelestarian alam dapat terancam akibat semakin meningkatnya pengeksploitasian alam. Oleh karena itu masyarakat adat Cigugur memiliki peranan penting sebagai local society control dalam pengelolaan alam. Keberadaan sumber daya alam yang melimpah berbanding lurus dengan mata pencaharian masyarakat yang mayoritas bekerja di bidang pertanian.

Pada tabel 2 menunjukkan masyarakat Kecamatan Cigugur mempunyai jenis pekerjaan beragam. Namun, jenis pekerjaan yang dominan diantaranya pertanian, perdagangan, 
dan jasa. Bidang pekerjaan lainnya masih berada di bawah ketiga bidang pekerjaan tersebut. Kondisi ini dapat dijelaskan bahwa masyarakat Kecamatan Cigugur masih mengandalkan sektor pertanian sebagai pekerjaan utama mereka. Adapun sektor jasa menjadi bidang pekerjaan yang diminati berikutnya, berkaitan dengan semakin tinggi tingkat pendidikan masyarakat sehingga diantaranya mereka dapat bekerja menjadi guru, konsultan, atau teknisi di perusahaanperusahaan di kota besar. Sementara itu perdagangan menjadi jenis pekerjaan yang diminati berikutnya. Kabupaten Kuningan sudah mulai mengembangkan program penggiatan pemberdayaan UKM yang ada di masyarakat. Sehingga usaha kecil menengah semakin bertambah disamping sebagian besar masyarakat yang sudah lama bergerak di bidang perdagangan.

Tabel 2. Jenis Pekerjaan Masyarakat Kecamatan Cigugur di Usia 10-59 Tahun

\begin{tabular}{llc}
\hline No & \multicolumn{1}{c}{ Jenis Pekerjaan } & $\begin{array}{c}\text { Jml } \\
\text { Penduduk }\end{array}$ \\
\hline 1 & Pertanian & 6710 \\
\hline 2 & Pertambangan dan Penggalian & 240 \\
\hline 3 & Industri Pengolahan & 1831 \\
\hline 4 & Listrik dan Gas & 354 \\
\hline 5 & Konstruksi/Bangunan & 2167 \\
\hline 6 & Perdagangan & 5029 \\
\hline 7 & Hotel dan Rumah Makan & 350 \\
\hline 8 & Angkutan dan Pergudangan & 1875 \\
\hline 9 & Informasi dan Komunikasi & 440 \\
\hline 10 & Keuangan dan Asuransi & 713 \\
\hline 11 & Jasa & 5620 \\
\hline 12 & Lainnya & 735 \\
\hline
\end{tabular}

Sumber : BPS Kabupaten Kuningan (2013, hlm.117)

Pekerjaan bidang pertanian yang mendominasi jenis pekerjaan masyarakat Cigugur menjadi sebuah indikator tingginya kebutuhan masyarakat akan sumber daya alam yang tersedia. Kondisi ini Selaras dengan kondisi topografi Kecamatan Cigugur, masyarakat memanfaatkan kondisi alam yang subur untuk diberdayakan sebagai lahan pertanian. Letak Kecamatan Cigugur yang berada di bawah kaki gunung Ciremai menjadikan kondisi tanah pertaniannya subur, fasilitas yang disediakan alam inilah yang dimanfaatkan sebaik-baiknya oleh masyarakat. Sejauh ini pemanfaatan lahan sawah dilakukan dengan baik sehingga masyarakat dapat memenuhi kebutuhan bahan pokok secara mandiri bahkan dapat dijual ke kota-kota lainnya di wilayah Jawa Barat. Namun demikian seiring bertambahnya jumlah penduduk, maka semakin meningkat pula kebutuhan akan bahan pokok beras. Kondisi inilah yang saat ini perlu diantisipasi dengan tepat dan berupaya dipecahkan oleh masyarakat di Kecamatan Cigugur.

Tingkat pendidikan masyarakat menjadi analisis berikutnya dalam memaparkan demografi penduduk Kecamatan Cigugur. Sebagian besar penduduk merupakan tamatan SD sebanyak 17.740 jiwa. Data tersebut menunjukkan indikator bahwa pendidikan di Kecamatan Cigugur berada pada taraf rendah. Namun demikian, secara berturut-turut jumlah penduduk lulusan SMP dan SMA berada pada posisi hampir berimbang yaitu 5.206 jiwa pada tingkat SMP dan 5.554 jiwa pada tingkat SMA. Kesadaran pentingnya melanjutkan pendidikan pada jenjang yang lebih tinggi sudah mulai timbul di masyarakat. Adapun jumlah tamatan Perguruan Tinggi hanya sebesar 1.248, jumlah tersebut tidak terlalu besar namun jika dilihat dalam skala kecamatan dapat dikatakan cukup tinggi. Jumlah ini menjadi modal yang cukup untuk membangun sumber daya manusia yang berkualitas, disamping itu masih terdapat harapan pada jumlah penduduk yang belum bersekolah sebanyak 7.334 jiwa dapat menjadi modal sumber daya manusia di masa depan. 
Pengelolaan lingkungan alam dan peningkatan kualitas masyarakat di masa mendatang dapat dijelaskan melalui tingkat pendidikan masyarakat sebagai modal sumber daya manusia dalam pembangunan.

\section{Pelaksanaan Nilai-Nilai Kearifan Ekologis}

Nilai kearifan ekologis masyarakat adat Cigugur untuk melestarikan lingkungan diantaranya terimplementasikan pada nilainilai yang terkandung dalam upacara seren taun dan pola hidup sehari-hari masyarakat memperlakukan alam dengan memperhatikan sustainable development atau pembangunan berkelanjutan. Sudut pandang ekologi manusia menunjukkan tindakan-tindakan tersebut sebagai hubungan timbal balik (interaksi dan interelasi) antara masyarakat lokal dengan lingkungannya. Sumaatmadja (2010:8) menyatakan bahwa unsur lingkungan yang terlibat di dalam hubungan interaksi dan interelasi tersebut meliputi lingkungan alam (lingkungan fisik), lingkungan sosial, dan lingkungan budaya. Lingkungan alam merupakan kondisi alamiah suatu wilayah, dalam hal ini meliputi kondisi iklim, tanah, fisiografi, dan batuan di lingkungan sekitar masyarakat adat Cigugur.
Hubungan interaksi masyarakat adat Cigugur dengan lingkungan alamnya dapat dilihat dari sistem pertanian, penjagaan leuweung larangan, pelestarian sungai, dan mata air/ cainyusu, serta nilai-nilai filosofis pelestarian lingkungan yang terkandung dalam upacara seren taun.

\section{Sistem Pertanian Masyarakat Adat Cigugur}

Mayoritas masyarakatnya mengelola lahan sawah sebagai sumber pemenuhan beras untuk kebutuhan pokok masyarakat. Lahan sawah seluas 692.843 Ha terhitung sangat memadai, namun pertumbuhan penduduk dari waktu ke waktu mengharuskan masyarakat memperhatikan aspek pengelolaan keberlanjutan. Masyarakat adat Cigugur memiliki kearifan lokal dalam melakukan pola tanam sawah dengan prinsip berkelanjutan. Pola tanam sawah yang dilakukan meliputi : mopok galengan, ngabaladahan, nebarkeun binih, babut, macul, nyongkog, dilahankeun, diirik, disurungan, digarit, tandur, diayuman, ngarambet, mupuk (digemuk), mipit/dibuat, dan $\mathrm{Nu/tu/Ngagiling}$ pare. Berikut siklus urutan pola tanam sawah yang dilakukan oleh masyarakat.

\section{Gambar 2. Siklus Urutan Pola Tanam Masyarakat Adat Cigugur}

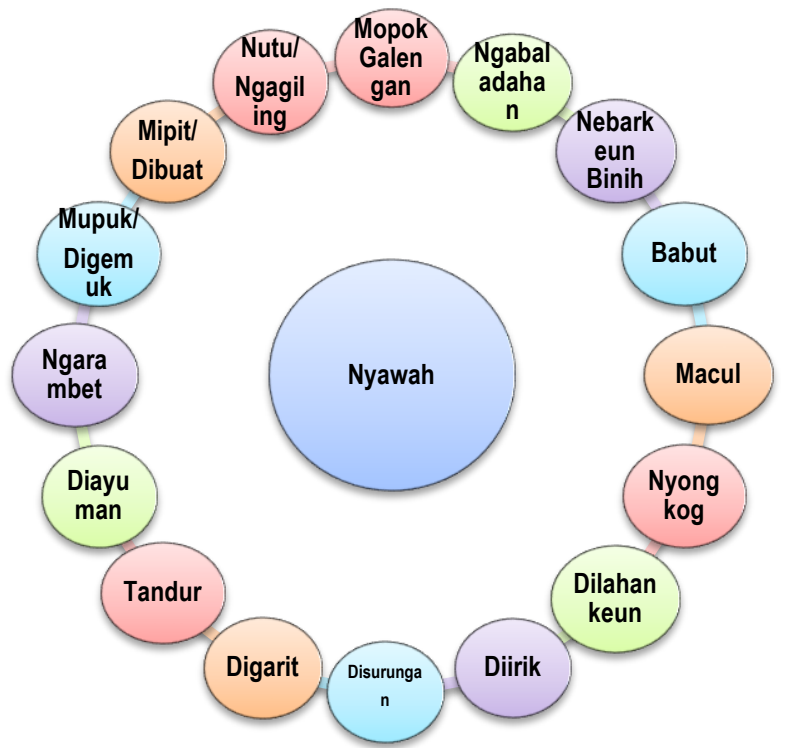

Sumber : Wawancara dengan Bapak Sunaryo 67 Tahun (12 Maret 2014) 
Masyarakat adat Cigugur memiliki nilainilai pelestarian lingkungan yang diimplementasikan dalam sistem pertaniannya. Peneliti menemukan nilai-nilai tersebut tidak hanya berupa ritual-ritual budaya kearifan lokal masyarakat yang sarat akan nilai-nilai luhur semata, melainkan juga sistem pengetahuan dan tindakan nyata masyarakat dalam pengolahan sawah. Nilai-nilai pelestarian tersebut dapat dilihat dari teknologi yang digunakan, proses pengolahan sawah, penggunaan pupuk, dan sistem pertanian berbasis lingkungan lokal (local eco-farming). Local Eco-Farming atau Pertanian Ramah Lingkungan (PRL) merupakan sistem pertanian yang mengelola seluruh sumberdaya pertanian dan input usaha tani secara bijak, berbasis inovasi teknologi lokal untuk mencapai peningkatan produktivitas berkelanjutan dan secara ekonomi menguntungkan serta diterima secara sosial budaya dan berisiko rendah atau tidak merusak/ mengurangi fungsi lingkungan.

Pertanian masyarakat berbasis sumber daya lokal memiliki kapasitas adaptif sebagai suatu sistem pertanian berkelanjutan yang ramah lingkungan. Antara lain, mereka behasil mengembangkan sendiri atau mengadopsi cara-cara pengembangan ekonomi pertanian ramah lingkungan dari lembaga supra lokal berbasis ketersediaan sumberdaya alam sekitar (lokal). Aspek-aspek dari pengetahuan dan kelebagaan lokal di bidang pertanian mencakup beberapa aspek, antara lain pengetahuan teknik produksi, kesepakatan komunitas, dan proses peng-ambilan keputusan dalam kaitannya dengan pilihan sistem pertanian ramah lingkungan, dan nilai-nilai sosio-budaya. Secara kongkrit seperti nilai-nilai dan normanorma dalam sistem pertanian organik. Aspekaspek ter-sebut digunakan oleh individu atau komunitas untuk menentukan pilihan terbaik dalam usaha pertanian organik guna memperoleh hasil terbaik pula. Karena itu, bagaimanapun pengetahuan dan kelembagaan lokal memiliki kemampuan lebih baik daripada pengetahuan ilmiah bila digunakan untuk menilai faktor-faktor resiko yang menyangkut keputusan-keputusan usaha pertanian lokal petani.

Pertama, pengetahuan organik secara lokal tersebut diperoleh dari hasil proses sosialisasi antar generasi, yakni pengetahuan yang telah dimiliki dan digunakan secara intensif oleh para orang tua (generasi sebelumnya) kemudian digunakan terus menerus pada genarasi sesudahnya hingga saat ini. Contohnya membuat pupuk kompos dari sisa makanan dan kotoran ternak dan limbah hasil panen padi (jerami) sudah dilakukan masyarakat adat Cigugur secara turun temurun. Dilihat dari konteks ini, maka sebenarnya istilah mengembangan pertanian organik pada intinya bukan menemukan pengetahuan yang baru sama sekali, tetapi para petani kembali pada sistem pengetahuan lama yang sudah digunakan oleh nenek moyang mereka di dalam aktivitas pertanian.

\section{Pola Penjagaan Leuweung Larangan}

Masyarakat adat Cigugur mendiami wilayah sekitar kawasan Taman Nasional Gunung Ciremai. Kehidupan sehari-hari mereka tidak terlepas dari kondisi alam pegunungan yang memiliki multimanfaat bagi kehidupan masyarakatnya. Gunung Ciremai menjadi kekayaan alamiah yang dimiliki oleh masyarakat adat sebagai sumber penghidupan sekaligus sarana interaksi manusia dengan alam sekitarnya. Hutan yang terbentang luas di sekitar kawasan gunung Ciremai menjadi 
sumber daya alam yang menjanjikan bagi masyarakat sekitar. Dengan demikian kondisi ini memungkinkan terjadinya pemanfaatan hutan secara berlebihan yang mengarah pada eksploitasi yang menimbulkan kerusakan hutan. Seperti pernah terjadi kasus kebakaran di hutan kawasan gunung Ciremai akibat penebangan liar pada 4 Oktober 2012 silam (Sumber: http://www.republika.co.id /berita/ nasional/nusantara-nasional/, diakses $24 \mathrm{Mei}$ 2014). Pelaku penebangan liar adalah masyarakat tidak bertanggungjawab dan luput dari pengawasan petugas.

Ancaman ekspolitasi hutan mendorong tindakan-tindakan preventif semakin digalakan untuk menjaganya agar tetap lestari. Pemerintah Kabupaten Kuningan bekerjasama dengan masyarakat menggiatkan disiplin penjagaan kelestarian hutan di kawasan gunung Ciremai. Masyarakat adat Cigugur sebagai salah satu komponen masyarakat Kabupaten Kuningan yang masih memegang teguh pikukuh adat istiadat leluhur turut serta menjaga kelestarian hutan di kawasan Gunung Ciremai. Sebagai salah satu stakeholder yang berperan sebagai control of society, masyarakat adat Cigugur turut serta memberikan peranan baik dalam pengawasan penegakkan hukum bagi masyarakat yang melakukan pelanggaran maupun sebagai kekuatan lokal yang konsisten memegang teguh prinsip kelestarian hutan. Melalui kearifan budaya lokal yang dimiliki, masyarakat adat Cigugur menegakkan aturan pikukuh leluhur khususnya untuk anggota masyarakat adat dan umumnya untuk masyarakat sekitar.

Aspek kekuatan lokal yang dipertahankan oleh masyarakat adat Cigugur adalah mereka telah sejak lama memiliki nilai-nilai kearifan lokal untuk menjaga kelestarian hutan. Berdasarkan wawancara dengan Gumirat Barna Alam (50 tahun), masyarakat adat
Cigugur memiliki aturan dalam menjaga kelestarian hutan dengan mengklasifikasikan fungsi hutan. Hutan (leuweng) dibagi menjadi tiga kategori yaitu leuweng geledegan, leuweng sampalan dan leuweng titipan. Tiga kategori tersebut mengacu pada ketentuan adat mengenai boleh atau tidaknya hutan tersebut untuk digarap. Leuweng geledegan/ leuweng kolot, merupakan hutan tua yang biasa dicirikan dari jenis hutannya yang masih lebat dengan berbagai jenis pohon besar dan kecil yang tumbuh secara alami. Ciri-ciri jenis hutan tersebut pepohonannya rimbun. Kerapatan pohon sangat tinggi dan masih banyak binatang hutan yang hidup didalamnya.

Daerah leuweng geledegan merupakan bagian tata guna lahan yang berada pada dataran paling tinggi di gunung Ciremai dan memiliki kelerengan lahan yang cukup curam. Kawasan ini juga berfungsi sebagai daerah resapan air, oleh karena itu daerah ini merupakan kawasan penyedia air bagi masyarakat dengan sumber mata air atau cainyusu didalamnya. Kawasan ini menjadi habitat atau tempat hidup berbagai macam binatang dan tumbuhan khas hutan alam gunung Ciremai yang dapat mendukung kehidupan di dataran di bawahnya. Apabila kawasan ini rusak maka keseimbangan alam akan terganggu dan bisa jadi terjadi bencana yang mengancam masyarakat. Bagi warga masyarakat adat hutan tersebut tidak boleh digarap secara adat hutan ini juga disebut sebagai leuweng tutupan.

Leuweng titipan merupakan hutan yang tidak boleh di ganggu atau dibuka karena dianggap keramat. Hutan ini tidak boleh dieksploitasi sama sekali, kecuali atas izin sesepuh adat. Leuweng titipan ini bagi warga masyarakat adat merupakan titipan dari para karuhun yang harus dijaga kelestarian dan keasliannya. Namun demikian, hutan ini dapat 
digarap dan dimanfaatkan jika telah mendapat izin dari sesepuh adat pada waktu-waktu keramat. Kawasan leuweung titipan masyarakat adat Cigugur terletak di Desa Palutungan Cigugur, di tempat tersebut terdapat tempat keramat yang diselimuti mitos adanya penunggu yaitu pasukan Prabu Siliwangi yang menghilang dan menunggui tempat tersebut. Pemerintah Kabupaten Kuningan melindungi situs ini untuk dijadikan salah satu cagar alam yang bisa menjadi salah satu khazanah budaya lokal. Selain itu secara khusus pemerintah menjadikannya sebagai salah satu komponen pendukung untuk menjaga kelestarian hutan.

Leuweng sampalan adalah jenis hutan yang dapat dikelola oleh masyarakat adat secara luas. Hutan tersebut dapat digarap dan dimanfaatkan seluas mungkin namun tetap dalam rambu-rambu adat. Warga boleh membuka huma ladang, kebun, menggembala ternak, mengambil kayu bakar dengan bebas. Hutan ini berada tidak jauh dari pemukiman penduduk. Berdasarkan pemahaman dan klasifikasi tentang hutan tersebut, warga masyarakat adat tidak boleh mengeksploitasi sembarangan hutan yang ada di wilayahnya. Mereka hanya boleh leluasa menggarap di dalam areal leuweung sampalan dan disitulah warga masyarakat adat Cigugur bercocok tanam dan berkebun untuk memenuhi kebutuhan hidupnya. Kawasan hutan tersebut boleh dimanfaatkan kapan saja dan berapapun luasnya. Hal tersebut tergantung kemauan dan kemampuan masyarakat dalam menggunakannya. Pembagian kawasan hutan oleh masyarakat adat secara nyata telah memberikan kontribusi bagi keutuhan dan kelestarian ekosistem hutan

Pembagian hutan masyarakat adat Cigugur ini juga sesuai dengan ilmu kehutanan yang membagi hutan menjadi hutan produksi, hutan produksi terbatas dan hutan lindung. Hal itu menjadi bukti bahwa kearifan lokal masyarakat adat Cigugur dalam mengelola sumberdaya hutan bisa diaplikasikan dalam sistem pengelolaan modern. Hasil wawancara yang dilakukan oleh peneliti pada tanggal 24 Mei 2014 dengan Barna Alam (50 tahun) menyebutkan bahwa masyarakat adat Cigugur memiliki beberapa aturan adat yang tidak tertulis dalam pengelolaan hutan. Aturanaturan tersebut mendukung pengelolaan sumberdaya hutan bisa memberikan manfaat yang berkelanjutan. Diantaranya : 1) Pelarangan Menggunduli Hutan. Masyarakat adat Cigugur mempunyai aturan tidak boleh menggunduli hutan yang ada di kawasan mereka. Hutan harus dijaga kelestariannya karena menurut warga apabila bumi ini gundul maka langit yang dianggap sebagai bapak tidak akan hidup rukun atau harmonis sehingga proses perkawinan tidak akan terjadi. Dengan demikian tidak akan terjadi hujan yang sangat diharapkan oleh masyarakat yang bermata pencaharian pokok bertani baik di lahan basah (sawah) maupun lahan kering (ladang/huma) yang membu-tuhkan curah hujan. Aturan pelarangan menggunduli hutan dikeluarkan untuk menjaga kawasan hutan sekitar lingkungan masyarakat adat Cigugur agar tetap lestari; 2) Pelarangan Penggunaan Pohon Rasamala. Masyarakat Adat Cigugur melarang meng-gunakan pohon Rasamala untuk bahan bangunan rumah, baik rumah penduduk maupun rumah adat. Pelarangan ini merupakan aturan leluhur karena menurut leluhur penggunaan pohon rasamala apalagi secara berlebihan dilarang bagi masyarakat adat. Kayu rasamala hanya dapat digunakan untuk membuat tempat peristirahatan atau saung, diambil daunnya untuk lalap dan diambil bibitnya untuk ditanam. Pelanggaran 
terhadap aturan ini akan memberikan dampak yang cukup berat seperti kebakaran dan kerusakan bangunan. Pelarangan penggunaan pohon Rasamala untuk bahan baku bangunan memberikan dampak positif terhadap kelestarian hutan. Hal ini karena keberadaan pohon Rasamala akan tetap utuh dan bisa mencapai umur puluhan bahkan ratusan tahun; 3) Pelarangan Menjual Hasil Hutan. Aturan lain yang dimiliki oleh masyarakat adat Cigugur dan sampai sekarang masih dipegang teguh adalah pelarangan menjual hasil hutan dari hutan titipan untuk dijual. Hasil hutan seperti kayu, rotan, dan bambu hanya diambil untuk keperluan sendiri, alat-alat memasak, kerajinan tangan, pagar dan lainnya, bukan untuk dijual. Pelanggaran terhadap aturan ini menurut cerita akan mendatangkan kualat atau kabendon. Aturan ini jika dipegang teguh secara nyata akan memberikan dampak positif bagi kelestarian hutan; 4) Ronda Gunung, secara bergiliran warga masyarakat adat Cigugur memiliki jadwal untuk melakukan ronda gunung secara berkala. Ronda gunung dimaksudkan untuk mengawasi lahan hutan mereka dari ancaman bahaya baik yang disebabkan oleh manusia maupun oleh hewan seperti babi yang banyak dijumpai di kawasan hutan gunung Ciremai. Ronda ini juga dimaksudkan untuk mencegah terjadinya pencurian kayu dan pelanggaran adat lainnya yang dilakukan oleh oknum-oknum di luar masyarakat adat yang tidak bertanggungjawab; 5) Pelarangan Menjual Tanah Ke Masyarakat Luar Cigugur. Warga masyarakat adat Cigugur secara adat tidak boleh untuk menjual tanah mereka keluar dari wilayahnya. Peraturan ini secara tidak langsung tetap menjaga kawasan dan wilayah mereka tetap berada dalam ruang lingkup aturan adat. Aturan ini juga memungkinkan warga untuk tetap mengelola tanahnya sesuai dengan aturan adat. Larangan ini menjadi tindakan nyata untuk menjaga keberlangsungan hidup masyarakat adat sekitar. Dikhawatirkan jika tanah dijual ke masyarakat luar, maka keberlangsungan nilai dan adat istiadat sekitar akan terancam dengan masuknya pengaruh luar.

Nilai-nilai yang terkandung dalam pola penjagaan leuweung larangan sangat bermakna bagi masyarakat adat Cigugur. Dari waktu ke waktu nilai-nilai tersebut terus dilestarikan sehingga memiliki derajat yang tinggi bagi masyarakat adat sekitar. Dengan demikian masyarakat adat Cigugur semakin menjunjung tinggi nilai-nilai yang diwariskan pada mereka mengenai pola penjagaan leuweung larangan. Kesadaran masyarakat adat Cigugur dalam menjaga kelestarian hutan ditanamkan juga dalam pepatah sehari-hari yang diajarkan secara turun temurun. Terdapat sebuah pikukuh yang diturunkan dari generasi ke generasi, salah satunya berbunyi "Gunung teu meunang dilebur, Lebak teu meunang diruksak, Larangan teu meunang dirempak, Buyut teu meunang dirobah". Pepatah tersebut memiliki arti gunung tidak boleh dihancurkan, lembah tidak boleh rusak, larangan tidak boleh langgar, dan amanat tidak boleh dirubah. Makna pikukuh itu antara lain tidak mengubah sesuatu atau dapat juga berarti menerima apa yang sudah ada tanpa menambahi atau mengurangi yang ada.

\section{Pola Penjagaan Sungai dan Mata Air}

Sumberdaya air yang terdapat di kawasan adat Cigugur digunakan dalam dua fungsi yaitu untuk memenuhi kebutuhan sehari-hari dan untuk ritual adat. Air diperlukan untuk memenuhi kebutuhan sehari-hari seperti untuk minum, masak, MCK (mandi, cuci, kakus), mengairi sawah, kolam ikan, dan memenuhi kebutuhan hewan ternak diambil dari sumber air bersih yang berasal dari empat mata air 
yaitu Citiis (Kelurahan Cileuleuy), Palutungan, Ciputri (Desa Cisantana), dan Cipari. Untuk mengalirkan air dari mata air ke tempat pemandian umum, menggunakan selang plastik/paralon dan bambu. Pemandian umum dan jamban terletak di atas kolam ikan sehingga rantai kehidupan berjalan baik.

Meskipun saat ini sebagian besar masyarakat sekitar sudah memiliki kamar mandi di dalam rumah, namun penggunaan pengelolaan sistem pembuangan masih menggunakan aturan lokal ramah lingkungan. Sebagian masyarakat sudah ada yang menggunakan jet pump untuk menarik air. Namun mata air yang ditarik adalah mata air Citiis dan penggunaannya masih terbatas. Penggunaan air secara berlebihan dianggap melanggar aturan masyarakat lokal karena secara tidak langsung mengurangi hak masyarakat lainnya yang membutuhkan. Selain penggunaan air yang berlebihan dikhawatirkan akan merusak cainyusu karena mengeksploitasinya tanpa pertimbangan persediaan untuk masa yang akan datang. Penjagaan cainyusu merupakan bagian dari budaya pamali yang memiliki norma-norma dan merupakan suatu bentuk konservasi sumber mata air yang dilakukan hingga saat ini oleh masyarakat adat Cigugur. Penge-lolaan sumberdaya air di dalam Hutan Keramat tidak dimanfaatkan untuk memenuhi kebutuhan masyarakat sehari-hari. Hal ini disebabkan adanya larangan dalam memanfaatkan sumberdaya yang ada di dalam Hutan Keramat demi kelestarian Hutan Keramat.

Adanya Budaya pamali dalam pengelolaan cainyusu terbukti menjaga kelestarian ekosistem di dalamnya maka sumberdaya air yang ada di dalamnya pun terjaga dengan baik. Budaya pamali di masyarakat adat Cigugur tidak mengalami perubahan dan peluruhan kearifan lokal. Hal ini dikarenakan masyarakat masih memegang teguh amanah yang disampaikan oleh leluhur mereka dan budaya pamali sudah menjadi landasan bagi kehidupan masyarakat adat Cigugur. Kearifan lokal budaya pamali diturunkan dari generasi ke generasi, yaitu dari generasi tua ke generasi muda sejak mereka kecil. Modal transfer of knowledge dilakukan dengan lisan/oral melalui cerita-cerita yang disampaikan dari genereasi ke generasi. Pendekatan melalui keluarga menjadi bentuk sosialisasi yang efektif untuk kelanggengan kearifan lokal pamali. Kearifan lokal yang berupa budaya pamali berhasil menjaga kelestarian hutan dan sumberdaya air di Cigugur. Kearifan lokal ini merupakan suatu bentuk aplikasi konservasi hutan dan air. Masyarakat secara sadar melakukan pengelolaan hutan dan air dengan berlandaskan budaya pamali yang telah dilakukan secara turun-temurun.

\section{Pola Konsumsi Masyarakat dan Aplikasi Reuse, Reduse, Recycle dalam Aktifitas Sehari-hari}

Konsep reuse, reduse, dan recycle (3R) merupakan konsep yang dikembangkan oleh Golleman (2012) sebagai upaya untuk meminimalisir pencemaran lingkungan. Ketiga konsep ini telah banyak digiatkan oleh para aktivis lingkungan sebagai media sosialisasi pelestarian lingkungan di masya-rakat. Secara konseptual 3R dikenalkan pada masyarakat dunia dalam kurun waktu yang terhitung masih baru. Namun ternyata masyarakat adat Cigugur telah menerapkan konsep 3R dalam kehidupan sehari-hari mereka dengan nama lokal yang berbeda. Masyarakat adat Cigugur sebagai masyarakat yang memiliki nilai budaya lokal khas telah memiliki aturan dalam mengatur kehidupan sehari-hari mereka. Termasuk pelaksanaan konsep reuse, reduse, dan recycle 
dalam menanggulangi pencemaran lingkungan di sekitar masyarakat adat Cigugur.

Paradigma masyarakat adat Cigugur yang mengedepankan keharmonisan dalam hidup (Tri Panca Tunggal) sangat selaras dengan konsep pembangunan yang berkelanjutan. Tri yang terdiri rasa-budi-pikir, panca adalah panca indera, dan tunggal adalah yang Maha Tunggal. Arti filosofisnya ketika manusia bisa mengharmoniskan, menyelaraskan atau menyeimbangkan rasa-budi-pikir lalu menerjemahkannnya melalui panca indera ketika mendengar, melihat, berbicara, bersikap, bertindak, melangkah, maka itulah yang akan memanunggalkan manusia dengan Yang Maha Tunggal. Konsep filosofis tersebut berdampak pada keselarasan hidup masya-rakat dengan alam, mereka menempatkan dirinya bagian dari alam untuk mencapai kedekatannya dengan Tuhan Yang Maha Esa. Nilai filosofis tersebut mampu meningkatkan kesadaran masyarakat untuk menyelamatkan masa depan masyarakat adat Cigugur diantaranya dengan menjaga lingkungan alam.

Konsep 3R dilaksanakan oleh masyarakat adat Cigugur dengan gerakan mengurangi timbunan sampah atau limbah secara konsisten dan berkelanjutan. Strategi tersebut dilakukan dengan mengimplementasikan 3R dalam setiap bidang kehidupan masyarakat. Masyarakat digalang untuk mengurangi (reduce) pemanfaatan sumber daya dalam berbagai aktivitas kehidupan. Dalam kehidupan sehari-hari masyarakat diajak untuk dapat memanfaatan kembali (reuse) benda yang telah dikonsumsi dan kalau memungkinkan melakukan upaya daur ulang (recycling) terhadap barang-barang yang telah dimanfaatkan. Masyarakat adat Cigugur selalu memanfaatkan kembali limbah/sampah yang dihasilkan baik limbah rumahtangga maupun pertanian yang berupa bahan organik menjadi pupuk (recycling), menggunakan kembali bahan-bahan atau alatalat yang ada setelah dipakai (reuse), serta paling utama dilakukan adalah mengurangi (reduse) penggunaan barang-barang yang berpotensi mencemari lingkungan seperti plastik, pupuk kimia, dan lain-lain.

Masyarakat adat memiliki pembagian pengelolaan sampah yang terdiri dari sampah organik dan anorganik dalam "bank sampah" yang dikelola oleh masyarakat. Sampah organik berupa sampah yang mudah terdegradasi secara alami, berasal dari makhluk hidup dan dapat dimanfaatkan untuk pembuatan pupuk kompos. Sampah Anor-ganik berupa sampah yang tidak dapat terdegradasi secara alami dapat dimanfaatkan kembali dengan cara di daur ulang. Pengelolaan sampah dilakukan melalui tahap pengumpulan, pengangkutan, pemrosesan, pendaur-ulangan, atau pembuangan pada material sampah yang dihasilkan dari kegiatan manusia. Tujuan pengelolaan adalah untuk mengubah sampah menjadi material yang memiliki nilai ekonomis dan mengolah sampah agar menjadi material yang tidak membahayakan bagi lingkungan hidup.

\section{PENUTUP}

Kearifan lingkungan (ecological wisdom) merupakan pengetahuan yang diperoleh dari abstraksi pengalaman adaptasi aktif terhadap lingkungannya yang khas. Pengetahuan tersebut diwujudkan dalam bentuk ide, aktivitas dan peralatan. Kearifan lingkungan yang diwujudkan ke dalam tiga bentuk tersebut dipahami, dikembangkan, dipedomani dan diwariskan secara turun-temurun oleh komunitas pendukungnya. Kearifan lingkungan dimaksudkan sebagai aktivitas dan proses berpikir, bertindak dan bersikap secara arif dan bijaksana dalam mengamati, memanfaatkan dan mengolah alam sebagai suatu lingkungan hidup dan kehidupan umat manusia secara 
timbal balik. Pengetahuan rakyat yang memiliki kearifan ekologis itu dikembangkan, dipahami dan secara turun-temurun diterapkan sebagai pedoman dalam mengelola lingkungan terutama mengolah sumberdaya alam. Pengelolaan lingkungan secara arif dan berkesinambungan itu dikembangkan mengingat pentingnya fungsi sosial lingkungan untuk menjamin kelangsungan hidup masyarakat.

Pengetahuan lokal yang sudah menyatu dengan sistem kepercayaan, norma dan budaya, dan diekspresikan di dalam tradisi dan mitos, yang dianut dalam jangka waktu cukup lama inilah yang disebut 'kearifan budaya lokal'. Pada makna yang sama berlaku diberbagai bidang yang berkembang di masyarakat, seperti bidang pertanian, pengelolaan hutan secara adat, pelestarian sumber air, secara umum dinyatakan sebagai kearifan lokal. Kearifan lingkungan dimaksudkan sebagai aktivitas dan proses berpikir, bertindak dan bersikap secara arif dan bijaksana dalam mengamati, memanfaatkan dan mengolah alam sebagai suatu lingkungan hidup dan kehidupan umat manusia secara timbal balik. Kearifan lingkungan dapat digali dari kearifan lokal yang fungsinya untuk konservasi dan pelestarian sumberdaya alam. Pengelolaan lingkungan dengan tetap mem-perhatikan kearifan lokal dapat merupakan upaya mempertahankan kearifan lingkungan.

Perkembangan nilai-nilai kearifan ekologis dalam budaya lokal masyarakat Cigugur Kuningan terlihat dari sistem budaya masyarakat adat Cigugur dan aturan dan norma masyarakat dalam menjaga lingkungan alam sekitarnya. Aturan dan norma yang disepakati masyarakat adat Cigugur dalam menjaga lingkungan alam sekitarnya berupa budaya pamali yang sudah diwariskan oleh leluhur. Pamali merupakan aturan dan norma yang mengikat kehidupan masyarakat adat Cigugur yang terungkap dalam prinsip-prinsip utama dikemukakan ketua adat sebagai aturan adat yang harus dipatuhi dan diyakini kebenarannya. Budaya pamali memiliki aturanaturan yang harus ditaati oleh masyarakat adat Cigugur. Setiap orang yang melanggarnya selalu mendapatkan balasan yang diyakini berasal dari karuhun. Aturan pamali mengandung nilai etika sosial, kesederhanaan, dan upaya menjaga kesehatan tubuh serta lingkungan.

Penggunaan masyarakat lokal sebagai sumber belajar IPS telah memberikan dampak positif bagi pengembangan kegiatan pembelajaran di kelas. Permasalahan yang seringkali dihadapi oleh guru mengenai keterbatasan sumber buku paket IPS dapat ditanggulangi dengan menjadikan sumber belajar tidak kaku hanya terfokus pada buku teks. Sumber belajar dalam IPS bisa diartikan secara lebih meluas diantaranya lingkungan sosial, budaya, ekonomi peserta didik seharihari. Pendekatan kontekstual menjadi alternatif yang bersifat kekinian untuk mengkorelasikan materi IPS dengan isu-isu sosial kontemporer di sekitar lingkungan tempat tinggal peserta didik. Selain itu penggunaan masyarakat lokal sebagai sumber belajar merupakan alternatif inovasi pembelajaran yang menarik perhatian peserta didik. Metode dan strategi pembelajaran yang dianggap monoton seringkali menimbulkan kebosanan bagi peserta didik.

\section{DAFTAR PUSTAKA}

Adimihardja, K. (2008). Dinamika Budaya Lokal. Bandung: CV. Indra Prahasta dan Pusat Kajian LBPB

Badan Pusat Statistik Kabupaten Kuningan. Kabupaten Kuningan Dalam Angka Tahun 2012. Kuningan: BPS Kabupaten Kuningan. 
Balitbang. (2013). Memahami Pertanian Ramah Lingkungan. [Online]. Tersedia: http://balitkabi.litbang.deptan.go.id/kilaslitbang/1326-memahamipertanian-ramahlingkungan.html. [7 Juli 2014]

Bevins,S and Wilkinson, N. (2009). Sustainability Across the Curriculum. Journal of Education For Sustainable Development. Los Angeles: Sage Publication (vol.3 No.2)

Chew, S. (2001). World Ecological Degradation: Accumulation, Urbanization, and Deforestation 3000 B.C.-A.D. Walnut Creek, CA: AltaMira.

Clugston, R. (2010). 'Earth Charter Education for Sustainable Ways of Living'.Journal of Education for Sustainable Development, 2010. 4: 157.

Costanza et. al. (2007). "Sustainability or Collapse: What Can We Learn from Integrating the History of Humans and The Rest of Nature?". Swedia : Journal Ambio Vol.36, No.7 (November 2007).

Domanska, E. (2010). "Beyond Anthropocentrism in Historical Studies". USA: Journal Historein Vol. 10.

Gadotti, M. (2010). 'Reorienting Education Practices towards Sustainability'. Journal of Education for Sustainable Development 2010 4: 203.

Goleman, D (2009) Ecological Intelligence: How Knowing the Hidden Impacts of What We Buy Can Change Everything. New York: Broadway Books

Goleman D., Bennet L., Barlow Z. (2012). Eco Literate, How Educators Are Cultivating Emotional, Social, and Ecological Intelligence. San Francisco: Jossey-Bass.

Hollingshead, B.P. (2005). 'Young People, Education and Sustainable Development:Exploring Principles,Perspectives and Praxis'. Journal of Education Sustainable Development 2010 4: 307.
Kahn, R (2010). Critical Pedagogy, Ecoliteracy, \& Planetary Crisis, The Ecopedagogy Movement, New York: Peter Lang.

Neolaka, A. (2008). Kesadaran Lingkungan. Jakarta: Rineka Cipta.

Otto, E. and Wohlpart, A.J. (2009). Creating a Culture of Sustainability Infusing Sustainability into the Humanities. Journal of Education For Sustainable Development. Los Angeles: Sage Publication (vol.3 No.2)

Rafsanjani, A. (2013). Ekoliterasi. [Online]. Tersedia: Heilraff.Blogspot.com /2008/ 05/ekoliterasi.html [9 Februari 2014]

Soemarwoto, O (2004). Ekologi, Lingkungan Hidup dan Pembangunan, cetakan kesepuluh, Jakarta: Djambatan

Somantri, N. (2001). Menggagas Pembaharuan Pendidikan IPS. Bandung: PT. Remaja Rosdakarya.

Spradley, J.P. (2007). Metode Etnografi. (Terjemah). Yogyakarta: Tiara Wacana.

Sumaatmadja, N. (2010). Manusia Dalam Konteks Sosial, Budaya dan Lingkungan Hidup. Bandung: Alfabeta.

Supriatna, N. (2011). 'Pengembangan Pendidikan Karakter melalui Green Curriculum dan Ecopedagogy dalam Pembelajaran IPS', makalah, dalamKonvensiNasional Pendidikan IPS di UPI, 14-15 Juli 2011.

Supriatna, N. (2012). 'Developing Green Behavior through Ecopedagogy in Social Studies Learning in Elementary School in Bandung, Indonesia' paper, presented at the eight Biennial Comperence of the Comparative Education Society of Asia (CESA 2012), Chulalongkorn University, Bangkok, Thailand, 2012.

Yayasan Trimulya. (1998). Cagar Budaya Nasional Gedung Paseban Tri Panca Tunggal Cigugur Kuningan Jawa Barat. Kuningan: Tidak Diterbitkan. 